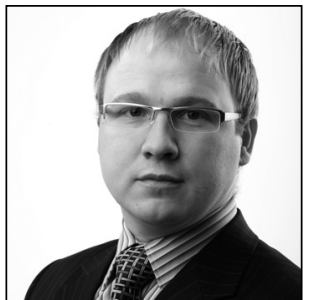

Anto Kasak

Mag. iur.

Attorney-at-Law

Partner, Kasak \& Missik Law Office

\title{
Is Full Preference for a Secured Claim in Insolvency Proceedings Justified?
}

\section{Introduction}

Credit is the cornerstone of the economy, because credit develops the economy. The more credit there is, the more an economy grows. The World Bank has supported this opinion, declaring that capital and credit are the lifeblood of the modern economy. ${ }^{* 1}$ Security instruments raise credit and thereby develop the economy. This argument is based on the assumption that lenders will issue more credit if credit is protected by security. The World Bank found also that secured transactions are of fundamental importance in a wellfunctioning market economy. ${ }^{{ }_{2}}$ The purpose of the security is to protect the investment. In other words, the interests of the security-holder are safely protected up to the value of the encumbered assets. Furthermore, if the debtor goes into bankruptcy, the claim of the security-holder is preferred to those of other, unsecured creditors. The secured creditor will receive the proceeds from the sale of the encumbered assets. As Prof. Reinhard Bork has noted, all cross-border insolvency laws respect giving preference to secured claims over unsecured ones. ${ }^{*} 3$ Therefore, preference for secured claims protects the instrument of security, which instrument is needed for healthy development of the economy. According to $\S 153$ (1) and (2) of the Bankruptcy Act of Estonia ${ }^{*}$, a secured claim is to be preferred over unsecured claims to the extent of the value of the encumbered assets, less the limited amount allocated to cover the payments related to the bankruptcy proceedings under $\S 146$ (1) of the same act of law. Financing the payments related to the insolvency proceedings from the proceeds from the sale of encumbered assets is another topic and beyond the scope of this article. In any case, taking into consideration that this exception is minor (in some cases, the funds allocated for this purpose might even not cover the costs of enforcement related to the encumbered assets), one can state that secured creditors have full priority over unsecured creditors in Estonia.

Legal scholars, among them professors LoPucki, Warren, Klee, Cantlie, Ziegel, Symes, and Finch, have published several papers questioning whether the security-holder indeed should be fully preferred in

1 World Bank. 'Principles for Effective Insolvency and Creditor/Debtor Regimes', available at http://pubdocs.worldbank. org/en/919511468425523509/ICR-Principles-Insolvency-Creditor-Debtor-Regimes-2016.pdf (most recently accessed on 1.5.2019), p. 3.

2 Ibid., p. 5.

3 R. Bork. Principles of Cross-Border Insolvency Law. Cambridge: Intersentia 2017, p. 173. - DOI: https://doi. org $/ 10.1017 / 9781780684659$

4 Pankrotiseadus (Bankruptcy Act). - RT I 2003, 17, 95 (in Estonian). 
insolvency proceedings. ${ }^{*} 5$ The author of the present article, too, questions the justification for full preference of secured claims with regard to insolvency proceedings. Therefore, the discussion below is aimed at analysing and ascertaining whether restriction of the secured creditors' rights in the insolvency proceedings is justified and necessary for balance of the credit system and the society as a whole, when one takes into consideration public interests and the interests of unsecured creditors. While credit is important for the development of the economy and there is a link between security and credit, an argument is presented by the author against the dogma that secured creditors shall be fully preferred in insolvency proceedings. The paper presents reasons for limiting the secured creditors' rights and offers one proposal for how a secured creditor's rights could be appropriately restricted in the interests of the whole society.

\section{The role of credit and securities}

\subsection{Credit as the circulatory system of the economy}

The essence of credit may be understood in any of several ways. From among a host of definitions, the author would like to quote this one, from the Cork Committee Report:

Credit is the lifeblood of the modern industrial economy. The most significant extenders of credit are banks and other lending institutions[,] such as finance houses or building societies. Manufacturers extend credit to customers and customers to manufacturers; the trade supplier extends credit to his customer; credit is the cornerstone of the trading community. ${ }^{* 6}$

Finnish author Jukka Kilpi succinctly noted that the history of credit extends far back into human history. Credit represents a pattern of social behaviour. ${ }^{* 7}$

It is widely agreed that credit is a necessary instrument for advancing the economy, with many scientists holding this opinion. Prof. R.M. Goode has found that credit is of value for running and expanding a business: credit gives the company an opportunity to do more business than would be possible with its own funds alone. ${ }^{*}$ Prof. P.R. Wood, in turn, concluded that financial institutions collect savings and borrow against this for productive enterprise, which is essential to modern economies. ${ }^{*}$ In line with the Cork Committee's finding that there is a link between credit and the financial health of a society ${ }^{*}$, Dennis and Fox have concluded that enlargement of the credit pool is important for solid development of the economy. ${ }^{* 11}$ All of these findings are consistent with the research conducted for the present article. The author agrees with these authors and finds credit to be indisputably an important instrument for healthy economic development.

Credit is used in two ways, as a loan and as an option for consuming goods or services without making payment at the same time (payment is deferred). Fiona Tolmie expressed a similar conclusion about two recognised possibilities for credit thus: there are the possibilities of sales credit and loan credit. Sales credit involves the creditor leaving the price for the goods or services outstanding but charging more to cover the risk. Loan credit, in contrast, entails lending of a sum of money with an agreement that the amount will be returned, along with the interest due. ${ }^{*} 2$ Dennis and Fox support this view, noting that credit may take the form of a loan or credit may be extended to enable the use of goods and services upon agreement for deferred payment. ${ }^{* 13}$ Both of these applications of credit are needed for the development of the economy.

5 J.E. Janger. 'Predicting When the Uniform Law Process Will Fall: Article 9, Capture and the Race to the Bottom.' - Iowa Law Review 83(1988), p. 619; J.S. Ziegel, S.I. Cantlie. Current Developments in International and Comparative Corporate Insolvency Law. Oxford: Clarendon Press 1994, p. 449; V. Finch, S. Worthington. 'The Pari Passu Principle and Ranking Restitutionary Rights' in F. Rose (ed.), Restitution and Insolvency. Mansfield Press 2000, p. 7; C.F. Symes. Statutory Priorities in Corporate Insolvency Law. Ashgate Publishing 2008, p. 134. - DOI: https://doi.org/10.4324/9781315242415.

6 K. Cork. Insolvency Law and Practice: Report of the Review Committee. London: Her Majesty's Stationery Office 1982, p. 10.

7 J. Kilpi. The Ethics of Bankruptcy. London: Routledge 1998, p. 9.

8 R.M. Goode. Principles of Corporate Insolvency Law. London: Sweet \& Maxwell 2011, p. 2.

$9 \quad$ P.R. Wood. Principles of International Insolvency. London: Sweet \& Maxwell 2007, p. 356.

10 K. Cork (see Note 6), p. 12.

11 V. Dennis, A. Fox. The New Law of Insolvency. Law Society Publishing 2003, p. 3.

12 F. Tolmie. Introduction to Corporate and Personal Insolvency Law. Sweet \& Maxwell 1998, p. 11.

13 V. Dennis, A. Fox (see Note 11), p. 3. 
Prof. I.F. Fletcher has discussed whether there can be any social system in which insolvency is impossible. For example, in the absence of credit, could a situation of insolvency occur? His conclusion is that credit is the root reason for insolvency. ${ }^{*} 14$ Kilpi too has concluded that non-payment may occur whenever credit is involved. ${ }^{*}{ }^{*}$ Furthermore, Dennis and Fox have added to the discussion the point that, by having entered into a transaction for credit, the debtor and the creditor have agreed on a degree of risk by creating a debt. The risk for the lender is that of non-payment of the debt, whether caused by personal failings, market forces, unforeseen contractual or tortious liability, or just plain misfortune. The risk for the borrower meanwhile is the potential penalty incurred for failing to repay the creditor on time. ${ }^{*}{ }^{*}$ The result is a two-edged sword - on one hand, credit is necessary for the development of the economy, but, on the other, credit is also the cause of insolvency. Therefore, efficient credit develops the economy, while inefficient credit causes insolvency.

The latter issue notwithstanding, credit is still needed, because business is not possible without capital. Dilation of capital is necessary for the vitality and growth of entrepreneurship. Merchants need money to start their own business and to keep it going. For receiving the capital required, they have to apply for credit. ${ }^{*} 17$ Taking these flows into consideration, the author concludes that, even though credit is the cause of insolvency, it remains a necessary instrument for the development of the economy.

\subsection{Security, necessary for more credit}

Prof. Wood noted that security increases capital and credit. ${ }^{*}{ }^{18}$ In the opinion of Prof. Goode, the primary purpose of the security instrument is the reduction of credit risk and assurance of priority relative to unsecured creditors in case of the debtor's insolvency. ${ }^{*} 19$ Prof. A. Hudson identifies insolvency risk as the risk of the insolvent person's incapability of accounting for any of said person's obligations. He adds that the risk is that one receives nothing in return from the insolvent person ${ }^{*}{ }^{* 0}$, whereas a security should protect the creditor from the risk of insolvency of the debtor. ${ }^{* 21}$ Similarly, Prof. Wood opines that a security should fully protect the creditor against insolvency of the debtor. ${ }^{{ }^{22}}$ Considering the reasons for utilising a security arrangement, Prof. V. Finch concluded that one major purpose is to have a privileged claim over unsecured creditors in the event of insolvency entailing distribution of the company's assets. ${ }^{* 23}$ Furthermore, E.A. Webber concluded that security has another vital role, in borrowing in pursuit of more productive business operations. Before deciding whether to extend a loan, the rational lender seeks a reasonable perspective on whether the loan will be paid back with interest. When a loan is secured, the lender has the right to receive a dividend from the sale of the collateral in the event that the debtor does not repay the loan. This mitigates the lender's risks and the costs of providing the loan. ${ }^{*} 4$ For that reason, a secured lender feels more certain about extending the loan than an unsecured lender, which unbalances the system as a whole.

Even the European Central Bank demands collateral before advancing funds to commercial banks. ${ }^{* 25}$ If one is able to offer a security, the likelihood of receiving a loan increases. In this connection, Prof. Finch indicates that banks demand security in the majority of commercial loan arrangements; obtaining security is the rule in relation to most cases of borrowing. A security arrangement is attractive to lenders because

14 I.F. Fletcher. The Law of Insolvency. London: Sweet \& Maxwell 2009, p. 4.

15 J. Kilpi (see Note 7), p. 9.

16 V. Dennis, A. Fox (see Note 11), p. 3.

17 M. Safley. The History of Bankruptcy. Oxon: Routledge 2013, p. 55. - DOI: https://doi.org/10.4324/9780203066836.

18 P.R. Wood. Principles of International Insolvency (see Note 9), p. 356.

19 R. Goode. Goode on Legal Problems of Credit and Security. London: Sweet \& Maxwell 2013, p. 1.

20 A. Hudson. The Law of Finance. London: Sweet \& Maxwell 2013, p. 30.

21 Ibid., p. 634.

22 P.R. Wood. Principles of International Insolvency (see Note 9), p. 356.

23 V. Finch. Corporate Insolvency Law: Perspectives and Principles. Second edition. London: Cambridge University Press 2009, p. 89. - DOI: https://doi.org/10.1017/CBO9781139175395.

24 E.A. Webber. 'The Tension between Bankruptcy and Secured Credit: A High-Level Overview of a Long-Standing Debate' in H. Peter, N. Jeandin, J. Kilbourne (eds), The Challenges of Insolvency Law Reform in the 21st Century. Genf 2006, p. 84.

25 G. McCormack, R. Bork. Security Rights and the European Insolvency Regulation. Cambridge; Antwerp, Belgium; Portland, OR: Intersentia 2017, p. 12. - DOI: https://doi.org/10.1017/9781780684987. 
it reduces their loan risk by granting them a privileged claim in the event of the debtor's insolvency. ${ }^{{ }_{2} 6}$ Research has shown that the security does indeed protect the interests of the security-holder against the risk of debtor insolvency in practice. The risk is prevented in such a way that the security-holder has the assurance that, whatever happens to the debtor, even insolvency, the encumbered assets will be sold and the security-holder's claim will be satisfied in the amount received from the sale of assets. Therefore, numerous writings have discussed the necessity of security instruments in the context of development of the economy.

This paper goes further, considering whether it has actually been proved that security is needed for the development of the economy or, instead, this is just widely believed dogma. The main arguments in support of securities are, firstly, that financial institutions will not grant unsecured loans in the same amount as secured loans and, secondly, that the costs of a secured loan, including those related to the interest rate, will be less than those for an equivalent unsecured claim. At the same time, Webber found that limiting the priority for the secured rights to the proceeds from realisation of the encumbered assets affects the market in the sense that secured credit is less readily available and is more expensive. ${ }^{* 27}$ From another angle, the author of the present piece argues that, since the purpose of a financial institution is to earn money via financing, which includes lending money, it would be rather unlikely that these institutions would not give loans without security. After all, holding the money without earning anything goes against the purpose of financial institutions. It seems clear also that interest rates will be subject to bargaining on the free market, and everyone is entitled to bargain equally for a 'fair' interest rate in the case of no security. We will not consider this topic further here, since it is a very broad one that is worthy of fuller analysis and discussion, elsewhere.

According to Prof. Wood, the advantages of security interests are the protection of creditors in regard of insolvency, availability of credit, reduced cost of credit, private rescue, and fair exchange for the credit. As for objections to security interests, one can cite the violation of bankruptcy equality, a position of excessive power held by the secured creditor, the risk of careless lending, priority risks, and that the secured creditor can disrupt a rescue. ${ }^{*} 8$ Prof. E. Warren found that, irrespective of the disagreement in academic discourse, security interests enjoy protection and bankruptcy law protects a secured creditor such that creditors with security interests generally enjoy better protection in bankruptcy than do those without them. ${ }^{* 29}$ Notwithstanding the large number of objections to security interests holding sway, the dominant opinion remains that the security instrument is necessary for the robust development of the economy. While general opinion holds that the security is necessary for economic development and that preference should be granted accordingly in insolvency proceedings, one can rightly express doubts as to whether the full priority typically afforded to secured claims in insolvency proceedings is justified. The arguments in support of the preference for secured creditors are analysed next, in this light.

\section{Giving preference to secured credit}

Prof. Bork notes that secured creditors enjoy preferential satisfaction of their claims up to the value of the collateral and that cross-border insolvency laws typically state expressly that foreign security rights are not affected by domestic insolvency proceedings. ${ }^{*} 30$ This illustrates well that preference for secured creditors is widely acknowledged in most jurisdictions. In author's opinion, the purpose of the security is the main factor in the preference granted to secured claims: the security protects the creditor against the risk of debtor insolvency. The security must be effective in the event of insolvency by conferring preference. Without the preference for the secured claim in insolvency proceedings, the security loses its purpose - protection of secured creditors. Prof. Finch found that, through security rights having priority over unsecured claims, the problematic effects of pari passu distribution are avoided. ${ }^{*}{ }^{1}$ Warren and Bussel add that a secured creditor's claim enjoys top priority in the hierarchy of claims: the secured creditor's claim will be satisfied

26 V. Finch. 'Security, Insolvency and Risk: Who Pays the Price?' - The Modern Law Review 62 (1999) / 5 (Sep.), p. 634. - DOI: https://doi.org/10.1111/1468-2230.00230.

27 E.A. Webber (see Note 24), p. 97.

28 P.R. Wood. Principles of International Insolvency (see Note 9), p. 356.

29 E. Warren. Chapter 11: Reorganizing American Business. Aspen Publishers 2008, p. 46.

30 R. Bork (see Note 3), p. 125.

31 V. Finch. Corporate Insolvency Law (see Note 23), p. 75. 
by the proceeds from the collateral sold, and every unsecured creditor's claim will be satisfied from the remaining amount insofar as possible after the secured claims are fully satisfied. ${ }^{*}{ }^{32}$ Similarly, Prof. Wood characterises secured creditors as super-priority creditors who are paid in full or up to the amount of the collateral and who can take assets out of the estate without constraint by the pari passu rule. ${ }^{*} 33$ The opinions that this is justified gains the support of Prof. R.J. Moksal, who has concluded that the secured creditor should have priority over other creditors and stand at the head of the queue for the pay-out from the sale of the collateral. ${ }^{*} 34$ Much of the literature concludes that a secured claim should be preferred with regard to insolvency proceedings, where 'preference' is defined as meaning that the debtor's insolvency does not affect the security-holder's right to receive the proceeds from the sale of the encumbered property. Again, if the security-holder's claim is equal to or greater than those proceeds, the unsecured creditors receive nothing from the sale of the encumbered property. Thus, the unsecured creditors and secured creditors are not treated equally, and secured creditors are granted preference when insolvency proceedings commence.

This preference for the secured creditors over unsecured creditors constitutes an exception to the pari passu principle. The question is, whether it is a true or a false exception to the pari passu principle. According to Prof. Goode, giving preference to secured creditors is a false exception to that principle, because encumbered assets do not truly belong to the company experiencing insolvency. ${ }^{*} 35$ The author of the present article would argue, in contrast, that whether it is, in fact, an exception to the pari passu principle depends on the legal system - that is, on whether or not the encumbered asset is among the insolvency assets in the relevant system. There are some systems - for example, in English insolvency law - in which encumbered assets do not belong to the debtor's company, while in other systems, such as that represented by Estonian insolvency law, encumbered assets are considered to belong to the debtor and hence are subject to enforcement by the trustee. This is the case also in Germany, but only for movables/claims, not for immovables. Prof. Wood notes that secured creditors are 'separatists' because secured creditors can pay themselves out of the collateral to the extent of its value by realising it. ${ }^{*}{ }^{6} \mathrm{He}$ explains that, even if security rights are preferred all over the world, it does not follow from this that secured creditors are always 'separatists'. That depends also on the legal system - i.e., on whether or not the collateral is part of the insolvency estate and whether the security-holder has the right to enforcement related to the collateral without the consent of the insolvency trustee.

Preference for secured creditors over unsecured creditors is an infringement of the principle of equal treatment of creditors. Prof. Fletcher has presented the principle of equal treatment of creditors as sometimes expressed by means of the Latin maxim 'par est condicio omnium creditorum' ${ }^{*} 37$; however, the preference extended to secured creditors is justified by another principle, referred to as the principle of respect for pre-insolvency rights. According to Prof. Finch, the pre-insolvency rights should be respected. One consequence of applying this principle is that proprietary claimants may assert their claims in specie against the defendant's estate. The remainder constitutes the pool of assets from which personal claims must be satisfied. ${ }^{*} 38$ Prof. Goode has noted that corporate insolvency law respects the rights obtained under general law prior to liquidation ${ }^{*} 39$, and Prof. D. Synvet too explains that the law of insolvency does not exist in isolation. A balance must be struck between insolvency law and other branches of law. The law on securities in rem creates situations involving exclusive rights. ${ }^{*}{ }^{40}$ Prof. D.G. Baird concludes that the exercise of bankruptcy law should respect the secured creditors' rights established under non-bankruptcy law; in bankruptcy proceedings, secured creditors should be treated approximately the same as outside the domain

32 W.D. Warren, D.J. Bussel. Bankruptcy. New York: Foundation Press 2002, p. 115.

33 P.R. Wood. 'The Bankruptcy Ladder of Priorities.' - Business Law International 14 (2013) / 3 (Sep.), p. 215.

34 R.J. Mokal. 'The Search for Someone to Save: A Defensive Case for the Priority of Secured Credit.' - Oxford Journal of Legal Studies 22 (2002) / 4, p. 688. - DOI: https://doi.org/10.1093/ojls/22.4.687.

35 R.M. Goode. Principles of Corporate Insolvency Law (see Note 8), p. 246.

36 P.R. Wood. 'The Bankruptcy Ladder of Priorities' (see Note 33), p. 215.

37 I.F. Fletcher. Insolvency in Private International Law: National and International Approaches. Oxford: Clarendon Press 1999, p. 9.

38 V. Finch, S. Worthington (see Note 5), p. 1.

39 R.M. Goode. Principles of Corporate Insolvency Law (see Note 8), p. 93.

40 D. Synvet. 'The Exclusion of Certain Creditors from the Law of Collective Proceedings' in W.-G. Ringe, L. Gullifer, P. Théry (eds), Current Issues in European Financial and Insolvency Law: Perspectives from France and the UK. Oxford; Portland, OR 2009, p. 160. - DOI: https://doi.org/10.5040/9781472560476.ch-011. 
of bankruptcy. ${ }^{*}{ }^{* 1} \mathrm{He}$ is supported in this view by Prof. T.H. Jackson, who suggests that priority rights established outside the scope of bankruptcy should be respected by bankruptcy law. ${ }^{*} 42$

As alluded to above, previous work has juxtaposed two principles. The first is the principle of equal treatment of creditors, and the second is the principle of respect for pre-insolvency rights. The implementation of these principles is sometimes contradictory. On one hand, every creditor should be treated equally, which means that secured creditors should be treated on par with unsecured creditors; on the other hand, pre-insolvency valid rights in rem should be respected in insolvency proceedings, which means that the security should be valid in insolvency proceedings and the secured creditor should be accorded preference over other, unsecured creditors. Security is obtained for the purpose of protecting the secured claim, which means that the security-holder can have confidence that, whatever happens, said creditor's claim is protected with collateral. Even if only one avenue were to render it possible to bypass protection of the secured claim, that claim would be cast into doubt, which leads, in turn, to uncertainty of the security. Researchers have argued that uncertainty of the secured claim would reduce the use of security instruments and, therefore, the amount of credit would fall, in consequence of which the development of the economy would suffer. According to Prof. B. Wessels, enforcing the principle of recognising the pre-insolvency rights helps to increase the credit available. ${ }^{*} 3$ In a similar vein, Prof. Fletcher found the creditors' expectation that their pre-insolvency rights in rem will remain valid in the event of insolvency proceedings to be an important element of the credit system on both national and international level. ${ }^{*} 4$ In addition, Webber cited the factor that businesses can obtain credit more readily, or on less burdensome terms, if they can provide the lender with security. ${ }^{*} 45$

The above-mentioned arguments suggest that respecting pre-insolvency rights will increase credit. Therefore, the prevailing understanding is that secured claims should be preferred in insolvency proceedings, lest decreased importance of security arrangements cause a decrease in credit; secured claims being regarded as equal to unsecured claims in insolvency proceedings would thereby impede development of the economy. This paper, however, challenges the view that secured claims should be fully preferred in insolvency proceedings, with an argument that a link between preference for secured claims in insolvency proceedings and expansion of the credit pool is not fully proven. It is posited that not the amount but the efficiency of the credit is decisive for development of the economy. Again, inefficient credit causes insolvency. Fair restriction of secured creditors' rights should make credit more efficient and develop the economy more efficiently.

\section{Restriction of the rights of secured creditors}

\subsection{Justification for the restriction of secured creditor's rights}

Earlier sections of this paper have pointed to views expressed by many authors holding that a secured creditor's rights should be fully preferred in insolvency proceedings. Still, there are some contradictory findings. Firstly, the Cork Committee Report already proposed taking a little from security-holders and distributing this relatively small sum among the unsecured creditors in purpose of relieving injustice and increasing the participation of unsecured creditors in insolvency proceedings. ${ }^{* 6}$ Professors LoPucki, Warren, and Klee are among the others who have argued against full priority of the secured creditor's claims in insolvency proceedings. ${ }^{*} 47$ Professors Ziegel and Cantlie suggested that the claims of the government and employees should have super-priority over secured claims, so as to increase the secured creditors' incentive to engage

41 D.G. Baird. 'Loss Distribution, Forum Shopping and Bankruptcy: A Reply to Warren' in J.S. Bhandari, L.A. Weiss (eds), Corporate Bankruptcy: Economic and Legal Perspectives. Cambridge University Press 1996, p. 106. - DOI: https://doi. org/10.1017/cbo9780511609435.012.

42 T.H. Jackson. The Logic and Limits of Bankruptcy Law. Harvard University Press 1986, p. 157.

43 B. Wessels. Cross-Border Insolvency Law. Kluwer Law International 2007, p. 609.

44 I.F. Fletcher. Insolvency in Private International Law (see Note 37), p. 10.

45 E.A. Webber (see Note 24), p. 85.

46 K. Cork (see Note 6), p. 32.

47 J.E. Janger (see Note 5), p. 619. 
in responsible monitoring. ${ }^{*} 8$ They added that giving super-priority to claims of government entities and employees too, should lead to more timely intervention in the actions of the potential debtor before insolvency occurs. ${ }^{*} 9$ Finally, Prof. Finch stated that arguments of fairness and efficiency do not justify complete preference of the claims of the secured creditors in insolvency proceedings and the corresponding disproportionate loss for the unsecured creditors. She also concluded that it is not clear why unsecured creditors should be discriminated against. ${ }^{*} 5$

The above conclusions are consistent with the research for the present paper. Although the reasons cited in the literature for restricting secured creditors' rights may vary, the results will be the same. While Prof. Ziegel and Prof. Cantlie argued for restricting the rights of secured creditors on the basis of the better monitoring and timely intervention that should ensue, for prevention of insolvency of the debtor ${ }^{*}{ }^{51}$, Prof. C.F. Symes suggested that in certain cases secured creditor's rights should be restricted in consideration of employees' rights. He explained that restricting the secured creditor's rights should shift some of the risk that can lead to insolvency from unsecured creditors partly to secured creditors. Again, in that case, monitoring of risks would be a task also for secured creditors, and the secured creditors have an incentive and perhaps greater opportunity to intervene earlier in the activity of the debtor and correct unsuccessful management as soon as possible. ${ }^{*}{ }^{2}$

Prof. Finch expressed the opinion that not only is full preference for security-holders inefficient and unjustified but there are no counter-arguments to justify it. ${ }^{*} 53$ The results cited in the relevant paper were contradicted by Prof. Mokal ${ }^{*} 54$, and a rather interesting debate about the matter followed between the two scholars. Their discussion focused on efficiency and justice, including arguments addressing involuntary creditors. While that debate provided a good starting point, one could rightly recommend that all possible reasons for restricting the secured creditor's rights be analysed together, not separately, and on a more general, abstract level. Hence, we now turn to some more high-level, abstract arguments in support of the restriction of a secured creditor's claim in a case of insolvency proceedings. The question of restricting the secured creditor's rights is, in fact, one with much wider implications than previously presented, where the general idea behind favouring such a restriction is an aim of forcing the security-holder to play a more serious part in the insolvency proceedings to the end of the rescue of the debtor.

Insolvency of a debtor is not merely a problem of the debtor or the creditor. It is also a problem of surrounding society. This view is consistent with findings of past studies as expressed in the Cork Committee Report and the work of Prof. Warren, Prof. Keay, and others. ${ }^{*} 55$ The main conclusion can be summarised thus: for sustainable environmental development, the interests of the debtor, the creditors (secured and unsecured creditors alike), and society as a whole should be balanced. Full protection of the security-holder retards the security-holder's interest in the future of the debtor. While remaining completely protected, the security-holder need not be interested in how the debtor's financial affairs develop. After all, the securityholder will receive the pay-out from the sale of the encumbered property in any case. Unsecured creditors, on the other hand, go totally unprotected, because the secured creditor's preferential position cannot be changed by their will; only the will of the debtor and the secured creditor matter. Hence, in the event of the debtor's insolvency, it is the unsecured creditors who are in the worst situation, incapable of taking any action to avoid the loss, while the security-holder's claim is fully protected even in cases wherein the reason for insolvency was precisely the continuation of the debtor's business activity as enabled by the conferring of additional credit via the secured loan. The secured creditor's decision to extend credit to the debtor should be contingent upon crucial importance to that creditor of having an interest in monitoring so as to intervene in the activity of the debtor in due time if necessary for purposes of the rescue of the debtor. Accordingly, restriction to protection of the secured creditor's rights should force the security-holder to be more interested in the debtor's activity both before and after the decision to extend credit. If the security-

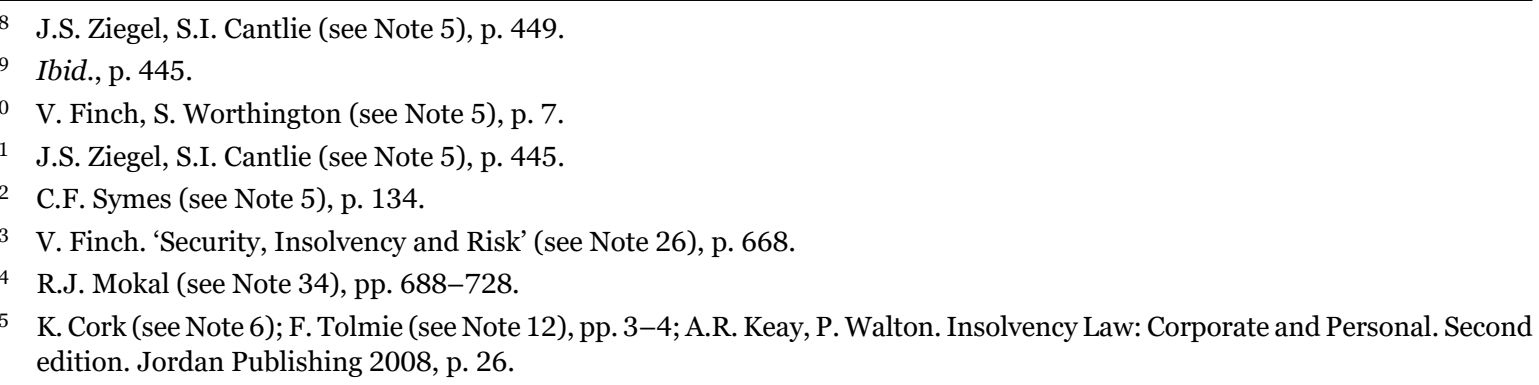


holder's rights are limited, said entity will lend more responsibly and will monitor the activity of the debtor more intensively and effectively, because there is good incentive to do so: otherwise, the risk of loss is going to increase. Restriction of a secured creditor's rights should force a prospective secured creditor to consider whether to offer a loan to this entity at this time. Better-considered decisions before secured credit is extended bring about more efficient lending. The number of risky secured loans should fall when a secured creditor's rights are restricted. Simultaneously, that restriction should force the secured creditors to monitor the activity of the debtor from the moment of enabling the loan all the way to the moment of the final payment on it. Again, in the absence of such restriction, the secured creditor has no concrete reason for monitoring the activity of the debtor: after all, the loan is secured against any outcome. This bears reiterating: in contrast, a secured creditor with restricted rights is more interested in minimising loss and maximising the unsecured income and, hence, is forced to monitor the activity of the debtor and to interfere, if doing so is needed, to rescue the debtor from insolvency. This is why restriction of the secured creditor's rights means not less credit but more effective credit. Finally, it is important to stress that the secured creditor's interest in actively avoiding the debtor's insolvency decreases the risk not only for the secured creditor but for the unsecured creditor as well. This would be an honest bargain, in that the creditor is protected and at the same time the unsecured creditors' risk is lowered and the actual interests of the debtor and society are set in good balance.

\subsection{Options for the restriction of secured creditor's rights}

The Cork Committee suggested an alternative to the existing regulation of floating charges. In summary, the committee proposed designating ten per cent of the encumbered estate as a 'fund'. The idea behind this fund is that the claim of a floating-charge-holder is decreased by ten per cent and the difference is distributed among the unsecured creditors. The Cork Committee proposed that, while the debenture-holder himself should not participate with the unsecured creditors in the ten-per-cent fund, the unsecured creditors could be prevented from doing better than the debenture-holder through imposition of an upper limit such that the percentage that the unsecured creditors recoup from their debts does not, in any event, exceed the percentage received back by the debenture-holder. ${ }^{*} 5^{6}$ The Cork Committee argued that such a system would ensure fair pay-out from the insolvent estate and could also encourage unsecured creditors to participate actively in governing the process of insolvency. In addition, it has been argued that increasing the pay-outs to the unsecured creditors helps them to remain in business themselves and also decreases the unfairness caused by the current ${ }^{*} 57$ floating-charge regulation as found in English law. ${ }^{*} 8$

Prof. Warren proposed a change to Article 9-301 of the Uniform Commercial Code of the United States. To wit, she proposed that twenty per cent of the proceeds from the sale of collateral in insolvency proceedings be set aside by the bankruptcy trustee to pay the claims of unsecured creditors. ${ }^{*} 9$

One option for restricting the secured creditors' rights would be to take a certain amount from the funds generated via the sale of the secured property and distribute it to the unsecured creditors. A sensible amount for the limit to the preference of the claims by security-holders might be the above-mentioned twenty per cent. In the remaining part, such claims should be addressed in the distribution to the unsecured creditors in line with the pari passu principle. Under this option, twenty per cent of the funds generated via the sale of the secured property shall be taken away from the secured creditor and distributed on pari passu terms among the unsecured creditors and, to the extent that his claim remained unsatisfied, the secured creditor.

For example, let us consider a case in which the security-holder has a claim of 100,000 EUR and the value of the secured assets is 100,000 EUR while there are unsecured claims that together amount to 80,000 EUR (with the first unsecured creditor's claim being for 10,000 EUR, the second for 30,000 EUR, and the third for 40,000 EUR), wherein the secured assets are sold for 100,000 EUR. Under $\S 153$ and $\S 154$ of the Bankruptcy Act of Estonia, the amount distributed to the secured creditor is 100,00o EUR and to the unsecured creditors is $\mathrm{o}$ euros, if the payments related to the insolvency proceedings are not taken into account. Even if the payments connected with the insolvency proceedings are considered, the pay-out

\footnotetext{
K. Cork (see Note 6), p. 347.

57 Here the committee report referred to the law that was valid at the time of the report's composition.

58 K. Cork (see Note 6), pp. 346-347.

59 J.E. Janger (see Note 5), p. 575.
} 
for each of the unsecured creditors is still o euros, while the secured creditor will receive a little less than the full amount due (paying the costs related to the insolvency proceedings from the proceeds of the sale of secured assets is another topic that would require more space than is available here, so the example is simplified for the present discussion). In contrast, if the option described above were applied in this scenario, the consequences would be the following. The secured assets are sold for 100,000 EUR, and eighty per cent of the proceeds, which comes to 80,000 EUR, will be paid directly to the secured creditor. The remaining amount from the sale, or 20,000 EUR, will be distributed under the pari passu principle to the unsecured creditors and to the secured creditor to the extent that his claim remains unsatisfied. In that case, there would be four unsecured claims (the first unsecured creditor's claim, for 10,000 EUR; the second unsecured creditor's claim, for 30,000 EUR; the third unsecured creditor's claim, for 40,000 EUR; and the unsecured claim amount remaining from the former security, in the amount of 20,000 EUR), which together come to 100,000 EUR. In accordance with the pari passu principle, from the remaining 20,000 EUR in proceeds, the first unsecured creditor will receive ten per cent (2,000 EUR), the second unsecured creditor will receive thirty per cent $(6,000$ EUR), the third unsecured creditor will receive forty per cent (8,ooo EUR), and the former secured creditor will receive twenty per cent (4,00o EUR). Thus, the entity that had the secured credit receives, all told, 84,000 EUR (80,000 EUR + 4,000 EUR) and the other, unsecured creditors receive, in total, 16,000 EUR (again, the first unsecured creditor getting 2,000 EUR, the second getting 6,000 EUR, and the third receiving 8,000 EUR). In the latter case, the secured creditor receives sixteen per cent less and each unsecured creditor receives twenty per cent more than if full preference had been given to the secured claim.

This author is of the opinion that taking that small amount away from secured creditors and distributing it among the unsecured creditors should motivate secured creditors and unsecured creditors alike to express interest and participate more in the activities of the debtor. The greater likelihood of earlier intervention by the secured creditor in the actions of a debtor headed for insolvency increases the chances of rescue of an insolvency-bound debtor and should reduce the liquidation rate among insolvent debtors. It is vital in this connection that a secured creditor who is keenly aware that the amount of the pay-out received from the insolvent debtor's assets depends on his actions will be more motivated to behave in a manner that encourages the maximum possible amount for that pay-out. This would be in the interest of all creditors. At the same time, the secured creditor does remain protected to eighty per cent of the value of the security plus the amount under pari passu in the remaining part. This author contends that taking away such a small amount from the secured creditor and distributing it among the unsecured creditors would not harm secured creditors so much as it makes credit more efficient and relieves injustice. More efficient credit does more for development of the economy than does inefficient credit, which causes more cases of insolvency. One negative consequence of this option might be more expensive credit, although that is far from a foregone conclusion, because credit rates would still be subject to bargaining in the market. The benefit would lie in more effective credit, which means that, as the outcome is articulated above, a secured creditor would be more interested in the behaviour of the debtor both before and after the decision to extend credit. The other benefits emphasised above are worth remembering too: better monitoring and earlier intervention by the secured creditor in the actions of the debtor, which should increase the number of cases of rescues of debtors headed for insolvency. With more efficient rescues, everyone involved in the market wins. Therefore, one can conclude that implementing this option would not harm the interests of the secured creditor as much as it helps to render the whole system more efficient.

\section{Conclusions}

It seems abundantly clear that credit develops the economy, but, although credit is necessary for the development of the economy, it is also the cause of insolvency. In that efficient credit develops the economy while inefficient credit leads to cases of insolvency, the efficient development of the economy requires that credit be as efficient as possible.

Though numerous objections to the security interest have been raised, the prevailing opinion is still that the instrument of security is necessary for robust development of the economy. General opinion holds that, the security being necessary for economic development, the security-holder should be preferred in insolvency proceedings; however, the present article has outlined strong doubts as to whether according 
full priority to secured claims in insolvency proceedings is justified. The challenge to the prevailing opinion is centred on an argument that a link between preference for secured claims in insolvency proceedings and expansion of the credit pool has not actually been proven. Again, the author proposes instead that it is not the amount but the efficiency of credit that develops the economy. Inefficient credit is the root of insolvency. Fair restriction of the secured creditors' rights makes credit more efficient and develops the economy more efficiently.

Full protection of the security-holder minimises that party's interest with regard to the future of the debtor. As long as the security-holder is fully protected, why does the security-holder need to be interested in the development of the debtor's financial affairs? The security-holder will be paid back from the sale of the encumbered property in any case. In contrast, the unsecured creditors are totally unprotected, because secured creditors' preferential position does not depend on their will; it is contingent only on the will of the debtor and the secured creditor. In these circumstances, the debtor's insolvency places the unsecured creditors in the worst situation, incapable of taking any action to avoid loss, yet the security-holder's claim is fully protected even in cases wherein the insolvency occurred precisely because the additional credit from the secured loan made it possible to continue the debtor's business activity. The secured creditor's decision to extend credit to the debtor is intimately bound up with finding the appropriate time for intervention in the activities of the debtor for the purpose of the debtor's rescue. Restriction of the protection extended to a secured creditor's rights should force the security-holder to be more interested in the activities of the debtor, both before and after the decision to grant credit. A security-holder whose rights are limited is going to lend more responsibly and monitor the activity of the debtor more intensively and effectively, because the risk of loss would increase otherwise. Again, the main outcome of restricting the secured creditor's rights is not actually less credit but more effective credit. A secured creditor's proactive efforts to avoid the debtor's insolvency decrease the risk not only for said creditor but also for each unsecured creditor. This would represent a true win-win scenario: the secured creditor is protected; at the same time, the unsecured creditors' risk is reduced; and the actual interests are balanced, including those of society.

The author is of the opinion that an amount of twenty per cent taken from the secured creditors and distributed over the unsecured and secured creditors' remaining claims under pari passu is an appropriate proportion to have the above-mentioned effect of motivating the secured creditor to take interest and participate more in the activities of the debtor. While not an overly burdensome amount, it should nonetheless create an incentive for earlier intervention of a secured creditor in the activities of a debtor headed for insolvency, thereby increasing the chances of rescue and decreasing those of liquidation of an insolvent debtor. In addition to the effect of the secured creditor, in the knowledge that the amount received from an insolvent debtor's funds is going to depend on his action, being more motivated to behave in a manner conducive to the pay-out being at its maximum (which is in the interest of all creditors), this amount ensures that the secured creditor remains protected to at least eighty per cent of the value of the security and the proceeds under pari passu in the remaining part. By the same token, again, removing so small an amount from the secured creditor and distributing it among the unsecured creditors is unlikely to harm the secured creditors so much as make the credit system more efficient and reduce injustice.

While more efficient credit has a more favourable effect for economic development than does inefficient credit (the latter yields insolvency), are there any possible negative consequences? This author disputes the notion that more expensive credit might result, since credit rates would be bargained for through market forces. This option should far outweigh any negatives through bringing more effective credit, via which a secured creditor would be more interested in the behaviour of the debtor (both prior to and after the decision on extending credit), and through encouraging better monitoring and earlier intervention on the part of secured creditors (such that more cases of rescue are possible and debtors' actions are subject to more appropriate scrutiny). Greater efficiency - whether at the rescue stage or before things progress that far means that everyone engaged in the market wins. Therefore, implementation of this option clearly will not harm the interests of the secured creditor as much as it helps to change the whole system, rendering it more efficient. 